\title{
Introduction to the new edition of Mad money
}

\author{
Benjamin J. Cohen
}

No one doubts the monumental role that Susan Strange played in the development of the modern field of International Political Economy (IPE). Starting in the 1960s, her work inspired generations of scholars to create a distinctive and remarkably robust British school of IPE. At the centre of her professional oeuvre was a fascination with the connections between money and politics, starting with her first book, Sterling and British Policy (1971), and continuing with such memorable volumes as Casino Capitalism (1986) and States and Markets ([1988] 1994). Fittingly, it was also the subject of her last book, Mad Money (1998), published just before her life was tragically cut short. The politics of money, it is safe to say, was never far from her thoughts.

\section{Key themes}

Not surprisingly, some of Strange's thinking about money showed significant change over time, reflecting the evolution of real-world events as well as her own steep learning curve. Most noticeable was her gradual shift from the state-centric perspective of her early work to a greater emphasis on non-state actors, as international capital markets revived and the pace of financial globalisation accelerated. During the 1970s her principal emphasis was on inter-state relations and the diplomacy of monetary negotiations. In this respect she was no different from most other specialists at the time (including myself), who also treated governments as the main actors involved. Market forces, insofar as they were considered at all, entered analysis as little more than a vexing constraint or complication for policy makers. More quickly than most others, however, she came to recognise the fundamental transformation being wrought by the 
reintegration of national financial markets and rapid increase of crossborder capital mobility. By 1986, in Casino Capitalism, she was already expressing concern about 'an international financial system in which the gamblers in the casino have got out of hand, almost beyond, it sometimes seems, the control of governments' (Strange 1986: 21). By 1998 she was convinced that the casino had gone crazy. 'The financial markets,' she wrote in Mad Money, have 'run beyond the control of state and international authorities' (Strange 1998: 1).

In a more fundamental sense, however, her thinking was remarkably consistent, stressing key themes over and over again in a variety of analytical contexts. Four themes, in particular, stand out.

First was the inherently political nature of money. 'No working politician', Strange wrote, 'needs to be reminded of the political nature of monetary policy ... Decisions concerning the management of money substantially affect other matters of great political sensitivity' (Calleo and Strange 1984: 91). More succinctly, 'the management of credit is necessarily highly political' (Strange 1985: 39, emphasis added). The basis of her view was historical, noting that with the transition from primitive to developed financial structures increased demands were placed on governments 'for the imposition of complex and precise rules to govern the operation of credit institutions and money markets' (Strange [1988] 1994: 97). The result, she felt, was an 'inseparability of money from politics' (Strange 1976: 20), not only at the domestic level but also, more to the point, at the international level, where governance structures are so much more ambiguous. From the beginning her scholarship was motivated by an almost missionary zeal to highlight 'the political element' that she saw as 'the missing component in much current discussion of international financial and monetary issues' (Strange 1971a: 216). Monetary management, she insisted, was inevitably 'bound up, in large part, with what might be called the "foreign policy" of money' (Calleo and Strange 1984: 91).

A second theme, following logically from the first, was the connection of money to power, with the arrow of causation running in both directions. If money was inseparable from politics, so too was the politics of money inseparable from considerations of power - particularly at the international level, where 'relationships between states are ultimately decided by relative power' (Strange 1971b: 39, emphasis added). Power was both the cause and the effect of monetary outcomes.

In Sterling and British Policy, for example, Strange distinguished four types of international currency: Top Currencies, Master Currencies, Negotiated Currencies and Neutral Currencies (Strange 1971b; also 1971a). Power entered her analysis as both causal variable and consequence. Economic and political influence, she averred, was critical in determining what moneys 
would qualify for any of these roles - the 'power factor affecting an international currency', as she put it (Strange 1971b: 38). The power derived from an international currency, in turn, could also be used to exercise political leverage over others - and most likely would be. In her words: 'It is highly probable that any state economically strong enough to possess [an international currency] will also exert substantial power and influence. The rich usually do' (Strange 1971a: 222). The 'foreign policies' of money would inevitably reflect how much power is possessed by each individual actor. Likewise, the structure of the monetary system as a whole will reflect 'the general world balance of political and economic power ... the relative power of states' (Calleo and Strange 1984: 99).

A third theme, in turn, concerned the general world balance that she spoke of and what it might look like. Strange assumed that the distribution of power in monetary affairs would almost certainly be highly asymmetric, with a small number of states enjoying a disproportionately large share of influence. For her, there was no doubting 'the reality of the inequality of power' (Strange 1976: 20). The global system was bound to be distinctly hierarchical, with control concentrated for better or worse in a 'small oligarchy of monetarily important states' (Strange 1976: 22) - the 'affluent alliance', as she called it in her usual colourful fashion (Strange 1976: 23).

Hierarchy was an obvious feature of her early analysis of international currencies (Strange 1971a, 1971b). It was also evident in her later discussions of global monetary management, which always laid stress on the desirability of effective collective action by the most powerful nations. No reform of casino capitalism was possible, she contended, 'beyond the limits of what is conceivably acceptable to the chief governments of leading states' (Strange 1986: 149). Money had become mad because 'the political foundations for international financial cooperation are weaker today than they were in the 1970s and 1980s' (Strange 1998: 43). Hierarchy implied privilege in her view, but also a measure of responsibility.

A final theme involved the United States, my own country, which Strange always regarded with a jaundiced mix of admiration and resentment. America, she insisted, was clearly primus inter pares, even within the affluent alliance and even where others perceived hegemonic decline. The US dollar was Top Currency - 'the choice of the market' (Strange 1971b: 5) - and the United States was 'lead player ... long accustomed to a dominant position' (Strange 1976: 43). Rumours of the demise of America's 'non-territorial empire ... the likes of which the world has never seen before' (Strange 1988: 13), particularly rampant in the 1970s and 1980s, were simply wrong - a 'myth of lost hegemony', she insisted (Strange 1987). Those who subscribed to the myth were misled by 'a rather narrow (and old-fashioned) understanding of power in 
world politics' (Strange 1985: 11). Even in the 1990s the United States remained 'the leading country of the world market economy' (Strange [1988] 1994: 115). In an age of increasingly mad money, only America retains 'the power if anyone has to reverse the process and tip the balance of power back again from market to state' (Strange 1990: 266).

But for Strange there was a problem - the fact that America too often acts 'in exactly the opposite way to that of a responsible hegemon' (Strange [1988] 1994: 115), 'guided by its own rather narrow view of national interest' (Calleo and Strange 1984: 117). In principle, the US should 'recognize its own true long-term national interest in exercising a wise hegemony over the world market economy' (Strange 1986: 171). In practice, it is more likely that others will have 'no other alternative [but] to submit to a measure of tyranny by the most powerful and ruthless member of the affluent alliance' (1976: 358). Strange did not exactly hate us Yanks, but she did find our behaviour a bit intolerable at times.

\section{A fitting capstone}

Mad Money may be considered a fitting capstone to Strange's long and productive career, encapsulating all of her key themes between the covers of one book. The volume is typical Strange (no pun intended) - brilliantly written; provocative, even iconoclastic, in tone; and imbued with a passionate concern for the problems of the real world. Intended as a sequel to her earlier Casino Capitalism, Mad Money addresses what she saw as a global financial structure gone crazy: a system in which 'financial markets [have] run ... far beyond the control of state and international authorities ... erratically manic at one moment, unreasonably depressive at others' (p. 1). For Strange, financial volatility has become 'the prime issue of international politics and economics' (p. 18, emphasis in the original), calling urgently for therapy of some kind. Disaster awaited if we could not find a way to prevent the sort of contagious crises that hit Mexico in 1994-95 and East Asia in 1997-98.

Mad Money begins in Chapter 1 with a recapitulation of the main themes of Strange's earlier Casino Capitalism, stressing the major policy decisions and non-decisions that, in her opinion, had first allowed financial markets seemingly to outgrow governmental control. The list includes many of the usual suspects, such as Britain's decision to reopen London as an international financial centre in the 1950s and the collapse of pegged exchange rates in the 1970s. It also includes, in a manner characteristic of Strange's imaginative mind, some unexpected entries, such as Europe's early resistance to more equitable burden-sharing in NATO or America's later refusal to negotiate a New International Economic Order. 
The chapter then adds a number of newer systemic developments that had emerged in the years after Casino Capitalism was published. Among these were the fall of the Berlin Wall and the emergence of Asian nations as major parties to the global financial system. Strange was particularly impressed by how much the system had grown and spread around the world, driven by the force of technology. In particular, she marvelled at the sheer size of the markets. Presciently, she noted two changes that later contributed directly to the global crisis that erupted in 2008. Both were astute observations. One was what she called the 'end of banking' (p. 9): the extent to which traditional commercial banks had become more like investment banks, increasingly tempted into risky proprietary trading - in her words, 'betting their own capital in the casino' (p. 9). The other was a massive shift in the regulatory environment from tight governmental supervision to a much greater reliance on self-regulation by financial institutions themselves. 'Hands-off', she lamented, 'was ideologically welcome and seemed also rationally justified' (p. 8). The stage, she worried, was set for tragedy.

Following this opening tour d'horizon, subsequent chapters go on to evaluate many of these developments in greater detail, covering the revolution in information technology (Chapter 2), interstate politics (Chapters 3 and 4), contagion risks (Chapter 5), global debt (Chapter 6), money laundering (Chapter 7) and the roles of both national governments (Chapter 8) and multilateral agencies such as the International Monetary Fund and Bank for International Settlements (Chapter 9).

In retrospect, some of Strange's discussion appears quaintly dated. In Chapter 3, for example, she puts great emphasis on the relationship between the United States and Japan - the 'US-Japan axis' - which she argues is crucial to the effective management of financial crises. That might have been true back in the 1980s, when the ascendant Japanese economy seemed unstoppable. But that was before the bursting of Japan's 'bubble' economy in 1989 and the quarter century of stagnation that followed. Strange acknowledges the seriousness of Japan's downturn after 1989 but seems unable to see it as anything more than a transitory event that would surely not diminish Tokyo's overall systemic influence. Japan's long, slow decline as a major player is nowhere anticipated, nor is the rise of China given anything more than a passing reference. Likewise, much is made in Chapter 4 of the importance of the Franco-German relationship, which she also sees as critical to underpinning the stability of the financial system. Here too she fails to anticipate subsequent developments that have essentially marginalised France's role in monetary affairs.

In other respects, however, Strange's words seem as apt today as when they were written. This is particularly evident in her Chapter 6, where she takes up the issue of transnational debt. The chapter is crucial to 
her argument. Not surprisingly, much of it is devoted to the 1994-95 Mexican crisis and the East Asian crisis that broke out two years later both still quite fresh in everyone's memory at the time. But Strange resists the temptation to limit her discussion to more traditional issues involving banks and sovereign debt. The challenge, she recognised, had become much broader, owing to the seemingly mad spread of financial activity around the world. More players had become involved on both sides of the markets. On the creditor side, conventional bank lending was now supplemented - and in many cases overshadowed - by the growth of securitised lending through national and international bond markets. Debt could now be easily traded, increasing the risk of contagious stampedes by frightened investors. On the debtor side, more and more borrowing was being done not by sovereign governments but by private entities, spreading risk even further. In her words, there were now 'various kinds of debtors, each with rather different problems and prospects' (p. 121). Could all these changes be successfully managed? Strange's worry was that 'the system seemed even further away from finding a long-term solution than it had been a decade earlier' (p. 121).

So how would it all end? All the strings of Strange's discussion are pulled together in a final Chapter 10, where she turns her eyes to the future. Notably, Strange resisted the temptation to offer any firm predictions of how matters might work out. 'We do not - cannot - know the future', she writes reasonably (p. 179). But she was prepared to offer some broad scenarios that could indicate 'possible directions in which the future might develop' (p. 179). Several relatively optimistic scenarios are mentioned but quickly dismissed as politically unattainable or utopian. She also outlines some possible solutions to the challenge of financial volatility - an eclectic collection of reforms including a closing down of offshore tax havens, cancellation of the debts of the world's poorest countries and creation of an international credit insurance corporation along lines proposed by the financier George Soros. Little hope, however, is held out that any of these might actually be adopted.

For Strange, the most likely scenarios were much darker. Two broad possibilities are outlined, both starting with a major financial collapse. In one case the outcome is general breakdown and a new Great Depression, replicating the sad experience of the 1930s. In the other, described as 'not a crash but a whimper', the outcome is closer to what might be called a Great Stagnation: deflation, prolonged and repeated recessions, a shrinkage of credit and perhaps a reversion to economic nationalism and trade protection. The first of the two possibilities, the 'Depression' scenario, is not out of the question, she warns, but could be averted by coordinated government action led by the United States. But if she had felt obliged to make a firm forecast, she would most certainly have chosen the second. 
The 'Stagnation' scenario, she concludes, 'is less dramatic and for that reason may seem more plausible' (p. 185). Strikingly, the scenario bears more than a passing resemblance to the shape of events as they have actually transpired in the world economy since the global crisis of 2008. It would not be unfair to describe Strange here as something of an oracle.

\section{Objections?}

Mad Money is not above criticism, of course. Mainstream economists, in particular, could easily find much to object to when Mad Money was published, starting with the initial premise. Had markets really run amuck? To most in the economics profession at the time, the chance of disaster appeared slim.

Few would have denied that there seemed to be a growing disjuncture between a financial structure that was increasingly global in scope and a political system still based on sovereignty defined in strictly territorial terms. Crises might indeed be more difficult to handle when huge amounts of money could so easily slosh across borders to destabilise currencies and torpedo economic policies. But for more conventional scholars, that simply reflected the hard truth of the decades-old Mundell-Fleming model, which highlighted the incompatibility of the three desiderata of capital mobility, stable exchange rates and autonomous monetary policy - the so-called 'Unholy Trinity'. Control over monetary policy clearly was weakened if governments insisted on currency pegs in a world of high capital mobility. By the same token, however, the effectiveness of fiscal policy was strengthened; and even monetary policy could regain potency if exchange-rate rigidity were relaxed. Strange tended to blur distinctions of this kind, preferring instead to speak boldly, if simplistically, of 'the traditional authority of the nation state' (p. 190). Economists would have preferred a more nuanced analysis of the instruments of macroeconomic management.

Likewise, one looks in vain for a systematic analysis of how the various pieces of her wide-ranging discussion fit together to form a coherent explanation of events or trends. The relevance of something like NATO burden sharing is never clearly demonstrated; nor are we told in any detail how cancelling the debts of poor countries would have helped alleviate the danger of financial crisis in emerging-market economies. Strange was much better at punching holes in the arguments of others than she was in articulating a comprehensive theory of her own.

Yet too much should not be made of such objections. Mad Money was never meant to abide by the standards of conventional social science. Not for Strange the dry bones of detached, positivist analysis. Her aim was far more didactic - to open eyes and rouse concern, much in the manner 
of an Old Testament prophet. A stylish writer who started as a journalist before moving to the world of scholarship, Strange was more interested in practical policy than abstract theory and had little taste for formal methodology. She was also inclined to challenge rather than respect the boundaries of traditional disciplinary paradigms. Technical details she left to others. For her, the issue was the larger context in which complex financial markets operate - the forest, not the trees. Her style emphasised the broad picture, not individual brush strokes.

'I never meant to be an academic', she once confessed. 'If I had had the chance ... I would have dearly liked to be an independent newspaper columnist' (1989: 429). The admission was telling. When we think of a newspaper columnist, we imagine someone who is both perceptive and articulate: whose interests are practical rather than abstract; whose style is informal, not formal; whose ideas are eclectic, unbounded by the limits of established disciplines. We read columnists for their opinions, not for weighty analysis. We value them for their insight, not their methodology. In short, we look for a shrewd observer, not a disciplined theoretician. Even in her most serious work, Strange exhibited all the best traits of a columnist. These are the standards by which Mad Money must properly be judged.

\section{Historical importance}

How, then do we assess the historical importance of Mad Money? Is this a book of truly lasting significance?

The course of events over the two decades since Mad Money first appeared may be said to confirm what the nineteenth-century German philosopher Arthur Schopenhauer had to say about new ideas. All truth, he said, passes through three stages. First it is ridiculed. Second, it is violently opposed. And then third, it is accepted as being self-evident.

Essentially, that is the story of Mad Money. When the book was first published by Manchester University Press, only Strange's most devoted fans in the United Kingdom were prepared to take her jeremiads seriously. Across the Atlantic, where the book appeared in a simultaneous American edition, the reception was cool at best. For some in the United States, including many of the leading lights of the American school of IPE, Strange was thought of as someone like the crazy aunt in the attic - tolerated, even beloved, but surely not to be allowed out into polite society. Her writings, so at variance with more conventional approaches, were dismissed as lightweight, if not downright silly. Her warnings of crisis were greeted with derision or anger. 
Yet clearly she was on to something. A crisis did erupt, just as she feared, and a repetition of the Great Depression was just narrowly averted. Today, with the 20/20 accuracy of hindsight, it has become clear to all how fragile the system had become. Strange may not have got all the details right. She certainly showed no awareness of the crucial role that a housing bubble in the United States would play in the drama that began in 2008; nor did she foresee the near collapse of the euro in ensuing years. But on the big picture she was right. Disaster was coming, and it would be painful. The truth is now considered self-evident.

She was not alone, of course. As Eric Helleiner (2011) has astutely noted, there were other IPE scholars who also correctly identified many of the dangers lurking in the mad monetary casino - among them, the American Ethan Kapstein (2006), the Canadian Geoffrey Underhill (1995) and the Scot Mark Blyth (2003). But as Helleiner readily acknowledges, such voices were in fact few and far between, and made little impact. For the most part, systemic risks were carelessly discounted.

The wonder is why. The vast majority of scholars - conventional economists and IPE specialists alike - could be fairly accused of a grave case of myopia. Memorably, even Queen Elizabeth was moved to ask, during a tour of the London School of Economics in late 2008: 'If these things were so large, how come everyone missed them?' As I have written elsewhere (Cohen 2009), the answer seems to lie in the framing effect of epistemology - the methodological standards that mainstream social scientists had set for themselves. By convention, most financial research at the time seemed biased toward midlevel theory building, focusing primarily on key relationships within a broader structure whose characteristics were assumed, normally, to be given and stable. Inquiry, in effect, was implicitly constructed to downplay the possibility of major systemic change. As Strange might have put it, the structure itself was simply not problematised.

And therein lies the lasting value of Mad Money. Regrettably, much IPE scholarship today continues to exhibit the same kind of myopia. The global structure is still not being problematised as it should be. Mad Money, however, does just that and thus provides us with a model of how the bigger picture might be studied. For anyone desiring to know how to distinguish the forest from the trees, this is the book to read.

\section{References}

Blyth, Mark, 2003, 'The political power of financial ideas', in Kirshner, J., ed., Monetary Orders: ambiguous economics, ubiquitous politics, Ithaca, NY, Cornell University Press, pp. 239-59. 
Calleo, David and Strange, Susan, 1984, 'Money and world politics', in Strange, S., ed., Paths to International Political Economy, London, George Allen and Unwin, ch. 6.

Cohen, Benjamin J., 2009, 'A grave case of myopia', International Interactions, 35 (4), pp. 436-44.

Helleiner, Eric, 2011, 'Understanding the 2007-2008 global financial crisis: lessons for scholars of International Political Economy', Annual Review of Political Science, 14, pp. 67-87.

Kapstein, Ethan, 2006, 'Architects of stability?', in Borio, C. E. V., Toniolo, G. and Clement, P., eds., Past and Future of Central Bank Cooperation, Cambridge, Cambridge University Press, pp. 115-52.

Strange, Susan, 1971a, 'The politics of international currencies', World Politics, 23 (2) (January), pp. 215-31.

Strange, Susan, 1971b, Sterling and British Policy: a political study of a currency in decline, London, Oxford University Press.

Strange, Susan, 1976, 'International monetary relations', in Shonfield, A., ed., International Economic Relations of the Western World, 19591971, vol. 2, London, Oxford University Press, pp. 18-359.

Strange, Susan, 1985, 'Interpretations of a decade', in Tsoukalis, L., ed., The Political Economy of International Money: in search of a new order, London, Sage Publications, ch. 1.

Strange, Susan, 1986, Casino Capitalism, Oxford, Blackwell.

Strange, Susan, 1987, 'The persistent myth of lost hegemony', International Organization, 41 (4) (Autumn), pp. 551-74.

Strange, Susan, 1988, 'The future of the American empire', Journal of International Affairs, 42 (1) (Fall), pp. 1-17.

Strange, Susan, 1989, 'I never meant to be an academic', in Kruzel, J. and Rosenau, J. N., eds., Journeys through World Politics: autobiographical reflections of thirty-four academic travelers, Lexington, MA, Lexington Books, pp. 429-36.

Strange, Susan, 1990, 'Finance, information and power', Review of International Studies, 16 (3) (July), pp. 259-74.

Strange, Susan, [1988] 1994, States and Markets, 2nd edn, London, Pinter.

Strange, Susan, 1998, Mad Money, Manchester, Manchester University Press.

Underhill, Geoffrey, 1995, 'Keeping governments out of politics', Review of International Studies, 21 (3), pp. 251-78. 